\title{
Article \\ Eco-Compatible Construction Materials Containing Ceramic Sludge and Packaging Glass Cullet
}

\author{
Fernanda Andreola ${ }^{1, * \mathbb{D}}$, Isabella Lancellotti ${ }^{1}$, Paolo Pozzi ${ }^{1}$ and Luisa Barbieri ${ }^{1,2}$ \\ 1 Department of Engineering “Enzo Ferrari”, University of Modena and Reggio Emilia, 41125 Modena, Italy; \\ isabella.lancellotti@unimore.it (I.L.); paolo.pozzi@unimore.it (P.P.); luisa.barbieri@unimore.it (L.B.) \\ 2 InterMech MO.RE., Interdepartmental Research Centre for Applied Research and Services in the Advanced \\ Mechanics and Motor Sector, University of Modena and Reggio Emilia, 41125 Modena, Italy \\ * Correspondence: andreola.fernanda@unimore.it; Tel.: +39-059-2056237
}

Citation: Andreola, F.; Lancellotti, I.; Pozzi, P.; Barbieri, L. Eco-Compatible Construction Materials Containing Ceramic Sludge and Packaging Glass Cullet. Appl. Sci. 2021, 11, 3545.

https://doi.org/10.3390/app11083545

Academic Editor: Joan

Formosa Mitjans

Received: 26 March 2021

Accepted: 12 April 2021

Published: 15 April 2021

Publisher's Note: MDPI stays neutral with regard to jurisdictional claims in published maps and institutional affiliations.

Copyright: (C) 2021 by the authors Licensee MDPI, Basel, Switzerland. This article is an open access article distributed under the terms and conditions of the Creative Commons Attribution (CC BY) license (https:// creativecommons.org/licenses/by/ $4.0 /)$.

\begin{abstract}
This research reports results of eco-compatible building material obtained without natural raw materials. A mixture of sludge from a ceramic wastewater treatment plant and glass cullet from the urban collection was used to obtain high sintered products suitable to be used as covering floor/wall tiles in buildings. The fired samples were tested by water absorption, linear shrinkage, apparent density, and mechanical and chemical properties. Satisfactory results were achieved from densification properties and SEM/XRD analyses showed a compact polycrystalline microstructure with albite and wollastonite embedded in the glassy phase, similar to other commercial glass-ceramics. Besides, the products were obtained with a reduction of $200{ }^{\circ} \mathrm{C}$ with respect to the firing temperatures of commercial ones. Additionally, the realized materials were undergone to leaching test following Italian regulation to evaluate the mobility of hazardous ions present into the sludge. The data obtained verified that after thermal treatment the heavy metals were immobilized into the ceramic matrix without further environmental impact for the product use. The results of the research confirm that this valorization of matter using only residues produces glass ceramics high sintered suitable to be used as tile with technological properties similar or higher than commercial ones.
\end{abstract}

Keywords: building materials; tiles; ceramic sludge; cullet glass; sintering; glass ceramics

\section{Introduction}

The circular economy is the answer to the linear economic model (take-make-dispose) which has created many problems of waste management. In circular economy, the flows of materials are biological, able of being restored into the biosphere, and technical [1-3]. Resource efficiency and zero waste are fundamentals concepts for the European Union, which is a net importer of natural resources. Countries, as Italy, whose are poor in raw materials, contribute negatively to increase the extraction of global resources. It is therefore necessary to extend the useful life of products and materials, minimizing the use of natural resources and reusing the products that have reached the end of their life, thus creating further value $[1,4]$. Furthermore, if a residue (in particular when coded as waste) can substitute a natural raw material and does not create negative environmental impacts, it can be perfectly placed within the economic circuit, thus becoming a good (the so-called end of waste, previously called secondary raw material) and thus increasing the safety of supply chain.

The tile industry occupies in Italy a relevant position in the national economy with a production of about 415 million $\mathrm{m}^{2}$ (2018) and an export volume of 338 million $\mathrm{m}^{2}$ [5] Referring to the world situation, Italy is the 6th largest producer of floor and wall tiles and the 1st country for internationalization (15 companies have a factory abroad). Eighty-two percent of the total national production is supported by about eighty companies located in a small area of $300 \mathrm{~km}^{2}$ in the North East (Modena and Reggio Emilia Provinces) [5,6]. 
Ceramic residues derive from process and depuration lines and can be classified as a function of both tiles production process and physical state. Residues classified from the process are:

- Unfired scraps originating in stages before firing (pressing, drying, glazing, etc.):

- $\quad$ scraps after firing and successive steps as tile selection, polishing, etc.;

- $\quad$ and from the depuration are:

- $\quad$ sludge (water content ranging from 40 to $80 \mathrm{wt} \%$ ) from clarification water and glazing step; and

- dust as exhausted lime from firing and atomization gases purification.

The ceramic sector is one of the most virtuous as it reintroduces almost all by products within its production cycle, with consequent environmental (reduction of dumping effluents and saving water consumption) and economic benefits [7-9]. The reuse factor of residues stands at an average value of $129 \%$. Furthermore, the majority of plants have an indicator higher than $85 \%$, the limit prescribed by the Ecolabel, but in any case always greater than $50 \%$ of the data associated with the BAT (Best Available Technologies) $[10,11]$.

However, decoration (traditional glazing or ink-jet printing) still represents a critical step from which wastewater treatment sludges originate [12-14]. The industries having both wet milling and spray-drying processes show a consolidate industrial practice, operating closed-loop recycling of the glazing wastewater to the body preparation process $(80-100 \%)[15,16]$. Approximately $90 \%$ of the ceramic plants have set their hydraulic balance to completely avoid the discharge of wastewater into the environment. Water is an important input in the following stages: Preparation of the raw materials suspensions (which are then fast dried and granulated for the spray dryer), and decorative lines and mills cleaning, in these steps the wastewater is completely recovered [9]. The problem appears when the companies have a partial cycle (without raw materials preparation and atomization step) or use dry milling and granulation for the preparation of the raw materials. In these cases, the process is not able to support the wastewater and it is necessary to separate the sludge from the purifying waters.

The problem of ceramic muds derived from the clarification of washing water plants, mills and glazing lines, basically consisting of ceramic paste residues, frits scraps, pigments, glazes, and pastes, is represented by the composition variability. This is related to the technological cycle, i.e., single-firing, double-firing, dry or wet grinding, etc. Within the body, besides the aluminosilicatic matrix, alkaline and alkaline-earth metal oxides are present, but also is possible to find heavy metals $(\mathrm{Pb}, \mathrm{Cd}, \mathrm{Cu}, \mathrm{Zn}, \mathrm{Cr}$, etc.) and chromophores hydroxides (Fe, Ti), such as components of frits, pigments and glazes. Further, additives and vehicles of organic nature used in digital decoration and iron and aluminium compounds used as coagulants for the flocculation are added [14,17].

In Europe, ceramic sludges are codified as special waste and classified as hazardous (European Waste Code 10.12.11*) or not hazardous (European Waste Code 10.12.11) as a function of the heavy metals and dangerous substances content $[18,19]$. Thus, sludge recycling can be a key factor regarding the reduction of both the use of natural raw materials and the environmental pollution avoided by the depuration treatment. Different examples, where ceramic sludges are used, are reported in literature: Engobe formulations $5-20 \mathrm{wt} \%[17,20]$, vitrification to produce new glazes up to $40 \mathrm{wt} \%$ [21,22], bricks (up to $40 \mathrm{wt} \%$ ) and roofing tile formulations (about $60 \mathrm{wt} \%$ ) [23-26], cements [14,27].

In literature glass-ceramics from waste were investigated [28], but they tended to. obtain different products for different applications and did not contemplate the use of ceramic sludges into the compositions. Some authors studied the obtainment of wollastonite-based glass-ceramics and its potential use in building materials (coating for floor and walls) using soda lime waste glass as $\mathrm{SiO}_{2}$ source and pure $\mathrm{CaO}$ [29]. Other studies proposed the use of waste glass cullet and coal fly ash as source of calcium with good results [30]. In these studies, the glass-ceramics were obtained by a conventional melting-quenching method and followed by controlled sintering process of the parent glass powders. 
In this paper, the novelty proposed by the authors is to obtain a monolithic glassceramic material suitable to be used as a floor or wall covering tile in building obtained by viscous flow powder sintering without previous melting of parent glass. The materials proposed are realized without the use of traditional ceramic raw materials, but only with recycled materials, i.e., ceramic sludge and packaging glass cullet $(50 / 50 \mathrm{wt} \%)$. Besides, the optimized thermal treatment allowed densification at lower temperatures than those used for commercial sintered tiles.

\section{Materials and Methods}

\subsection{Laboratory Scale Material Preparation}

Two representative sludge samplings resulting from the wastewater ceramic process were chosen. The materials were dried $\left(110^{\circ} \mathrm{C}, 24 \mathrm{~h}\right)$ and mixed to obtain a homogeneous mixture. The glass cullet used is an Italian commercial product (called Glassy sand) derived from the secondary process of reclaiming the packaging glass waste from primary treatment. The as received glass sample is available as granules with a diameter range of 400-800 $\mu \mathrm{m}$. From an industrial ceramic point of view, that is, to create glass-ceramics by viscous flow sintering with formation of a liquid phase and consequent elimination of the gas phase and of the intergranular pores, ceramic sludge and glass cullet were ground separately to obtain fine powders, and two sizes were selected $(<125 \mu \mathrm{m}$ and $<75 \mu \mathrm{m})$. A mix with $1 / 1$ ratio of the two raw materials was selected, resulting the best in view of using the maximum quantity of sludge, but to have a necessary and sufficient glassy phase to obtain a specimen not deformed and partially crystallized.

Mixtures with $50 \mathrm{wt} \%$ of each component at two sizes were prepared, homogenized by a slow mill for $30 \mathrm{~min}$. The final particle size of the mixtures (V125 and V75) was measured by a laser diffraction analyzer (Malvern Sizer 2000, Malvern, UK). The characteristics diameters for V75 $\mathrm{d}_{50}=15.76 \mu \mathrm{m}$ and $\mathrm{d}_{90}=53.59 \mu \mathrm{m}$ and for V125 $\mathrm{d}_{50}=17.80 \mu \mathrm{m}$ and $\mathrm{d}_{90}=70.42 \mu \mathrm{m}$ were determined. The specimens were obtained shaping by coldcompacting the powders mixture followed by heat treatment to sinter the compact using a common route for the fabrication of ceramics and also employed for glass-ceramic production [28].

In order to obtain a humidified mixture suitable for the pressing, a water content of $6 \mathrm{wt} \%$ was added. The cilindre ( $40 \mathrm{~mm}$ diameter, $5 \mathrm{~mm}$ thickness) specimens were obtained at $40 \mathrm{MPa}$ (Uniaxial Press Mignon C, Nannetti srl, Faenza, Italy). The samples were put in oven at $105{ }^{\circ} \mathrm{C}$ overnight and then undergone to different thermal treatments $(800,900$, and $1000{ }^{\circ} \mathrm{C}$ ) with isotherm of 30 and $60 \mathrm{~min}$. in a laboratory electrical furnace (Lenton, model AWF 13/12, Hope Valley, UK). Finally, the fired compacts were characterized.

\subsection{Test Methods}

The densification degree of fired samples was studied by the determination of the water absorption $(W A \%)$, linear shrinkage ( $L S \%)$ and apparent and absolute densities.

Water absorption (WA\%) was measured by the Equation (1), where, $m_{i}=$ mass of dried specimens, $m_{f}=$ mass of saturated specimens after boiling in distilled water for $2 \mathrm{~h}$.

$$
W A \%=\frac{m_{f}-m_{i}}{m_{i}} * 100 .
$$

Linear shrinkage ( $L S \%)$ was determined by measuring the percentage changes in the diameter of the samples. The values were calculated by Equation (2), where $L_{g}=$ length of dried green sample; $L_{f}=$ length of the fired sample. The determinations were performed using an electronic caliper (accuracy: \pm 0.01 ).

$$
L S \%=\frac{L_{g}-L_{f}}{L_{g}} * 100
$$

The $L S \%$ and $W A \%$ tests were carried out on ten representative specimens and the average data was reported. 
The apparent density $\left(D_{a p}\right)$ of the fired samples was analyzed by an envelope density analyzer (GeoPyc 1360, Micromeritics, Norcross, GA 30093, USA) based on Archimedes principle. The use of DryFlow ${ }^{\circledR}$ as medium in substitution of traditional solvents or mercury is a novelty and permits to obtain a high accuracy degree [31]. The density values obtained are an average of 5 measures and the standard deviation is calculated. The absolute density $\left(D_{a b s}\right)$ was measured by gas (He) pycnometer (AccyPy1330, Micromeritic, USA), in order to calculate the total porosity values $(P \%)$ of samples according to equation (Equation (3)).

$$
P \%=\frac{D_{a b s}-D_{a p}}{D_{a b s}} * 100 .
$$

The characteristic temperatures and sintering behavior were estimated by an optical hot stage microscope (HT Misura 3.32, Expert System Solutions, Modena, Italy) using a temperature gradient of $10^{\circ} \mathrm{C} / \mathrm{min}, \mathrm{Tmax}=1400{ }^{\circ} \mathrm{C}$ and by an optical dilatometer (Misura ODHT, Expert System Solutions, Modena, Italy) with a temperature gradient of $50{ }^{\circ} \mathrm{C} / \mathrm{min}, \mathrm{T}_{\max }=1000{ }^{\circ} \mathrm{C}$. The thermal behavior was analyzed by Thermal Differential Analysis (TG/DTA STA 429CD, Netzsch, Selb, Germany) with the following parameters: $\mathrm{T}$ range $=20-1400{ }^{\circ} \mathrm{C} ; \Delta \mathrm{T}=20^{\circ} \mathrm{C} / \mathrm{min}$, sensibility $=0.1 \mu \mathrm{g}$.

On the fired samples a deep characterization was performed. Mineralogical analysis was carried out by X-Ray Powder Diffraction analyzer (PW 3710, Philips Research Laboratories, Netherlands) with Ni-filtered $\mathrm{CuK} \alpha$ radiation in $5-70^{\circ} 2 \theta$ range and speed $1^{\circ} / \mathrm{min}$, operating at $40 \mathrm{~mA}$ and $40 \mathrm{keV}$. Highscore Plus software version 3.0 [32] coupled to the International Centre for Diffraction Data (ICDD) cards database were used to identify the crystalline phases. Microstructural analysis was conducted by SEM (Model XL40, Philips Research Laboratories, Eindhoven, The Netherlands) coupled with X-EDS equipment (Model QUANTAX-200, Bruker, Germany).

MIP- Mercury intrusion porosimetry (Autopore IV9500, Micromeritics, Norcross, GA 30093, USA) was carried out to measure pore size distributions, total pore volume, total pore surface area, etc. The measures were conducted with the following operative conditions: the equilibrium time (10 s) between pressure limits of $345 \mathrm{kPa}$ and $228 \mathrm{MPa}$ that permits to identify capillary pores between 0.006 and $350 \mu \mathrm{m}$.

Elastic properties were evaluated using an instrument for non-destructive measurements based on Impulse Excitation Technique (IET) (Model Electronika MK5, Grindosonic LTD). The test highly accurate and very simple is in agreement with the ASTM 1259 testing method for dynamic elastic modulus. The calculation of Young (E), shear modulus $(\mathrm{G})$ and Poisson ratio $(\mu)$ values were performed using samples' geometric and weight data through EMOD software program [33].

Tests to evaluate the chemical resistance to acids $(\mathrm{HCl} 3 \mathrm{vol} \%)$ and the staining resistance (olive oil and a green pigment $\left(\mathrm{Cr}_{2} \mathrm{O}_{3}\right)$ were conducted on three specimens for each trial following UNI EN ISO rules.

Taking into account the presence of heavy metals in ceramic glazing sludge, leaching tests, following the UNI 10802 rule (EN 12457-2, 2002), were performed on the as-received sludge and on the sintered products. The samples were ground below $4 \mathrm{~mm}$ and immersed in deionized water (10/1 liquid/solid ratio) in capped bottles and shaken for 1 day at room temperature. The analysis was performed on the eluate separated by filtration using a cellulosic membrane $\left(\mathrm{D}_{\text {pore }}=0.45 \mu \mathrm{m}\right)$. The $\mathrm{pH}$ and specific conductivity were measured by pHmeter Crison-Basic 20 and Radiometer Analytical-Meterlab CDM210, respectively. According to UNI EN ISO 5667-3 rule, the eluate was conserved for successive chemical analysis by ICP/OES (Varian Analytical, mod. Liberty 200), metals and anions were determined at the $\mathrm{pH}=2$, obtained by adding drops of $\mathrm{HNO}_{3} 65 \%$ (aq), and the results were compared to the Italian regulation limits.

\subsection{Semi-Industrial Scale Experimentation}

The semi-industrial experimentation was carried out in a ceramic company where the samples were fired in industrial roller kilns with different cycles usually used for 
two commercial porous products called monoporosa and double firing. As suggested by laboratory tests, three cycles with different operative conditions were chosen: $960^{\circ} \mathrm{C}$, $50 \mathrm{~min} ; 1020^{\circ} \mathrm{C}, 54 \mathrm{~min}$ and $1087^{\circ} \mathrm{C}, 41 \mathrm{~min}$. For the semi-industrial scale tests only, the finer mix V75 (powders $<75 \mu \mathrm{m}$ ) was selected due to better laboratory results. The samples used for this experimentation were prepared using the same laboratory tile making procedure described above.

\section{Results}

The chemical analysis of ceramic sludge (Table 1) shows high levels of $\mathrm{SiO}_{2}$ and $\mathrm{Al}_{2} \mathrm{O}_{3}$, and the presence of $\mathrm{Na}_{2} \mathrm{O}, \mathrm{K}_{2} \mathrm{O}, \mathrm{CaO}$ and $\mathrm{MgO}$ typical oxides of ceramic pastes. Besides, the presence of $\mathrm{ZrO}_{2}$ used in frit and pigment components, $\mathrm{Fe}_{2} \mathrm{O}_{3}$ and $\mathrm{TiO}_{2}$ used as chromosphere oxides and heavy metals $(\mathrm{Pb}, \mathrm{Cu}, \mathrm{Cr}, \mathrm{Ba}, \mathrm{Zn})$ derive from the decoration glaze and frits components. Instead, glass cullet reveals a typical composition of sodium-calcium silicate glass.

Table 1. Chemical analysis (XRF) of raw materials used.

\begin{tabular}{ccc}
\hline $\begin{array}{c}\text { Oxide } \\
(\mathbf{w t} \% \mathbf{)}\end{array}$ & Ceramic Sludge & Glass Cullet \\
$\mathrm{SiO}_{2}$ & 52.36 & 71.16 \\
$\mathrm{Al}_{2} \mathrm{O}_{3}$ & 19.37 & 2.39 \\
$\mathrm{CaO}$ & 5.73 & 9.98 \\
$\mathrm{MgO}$ & 2.43 & 2.03 \\
$\mathrm{Na} O$ & 3.9 & 12.63 \\
$\mathrm{~K}_{2} \mathrm{O}$ & 1.32 & 1.34 \\
$\mathrm{Fe}_{2} \mathrm{O}_{3}$ & 0.84 & 0.10 \\
$\mathrm{TiO}_{2}$ & 0.45 & 0.02 \\
$\mathrm{BaO}$ & 0.54 & 0.12 \\
$\mathrm{ZnO}$ & 0.99 & 0.04 \\
$\mathrm{PbO}_{\mathrm{CuO}}$ & 0.49 & 0.02 \\
$\mathrm{Cr}_{2} \mathrm{O}_{3}$ & 0.10 & 0.04 \\
$\mathrm{ZrO}$ & 0.07 & - \\
$\mathrm{Others}_{2}$ & 3.01 & 0.13 \\
$\mathrm{~L} . \mathrm{O} . \mathrm{I}$ & 0.50 & - \\
$\mathrm{TOTAL}_{\mathrm{CaCO}}$ & 8.00 & - \\
\hline
\end{tabular}

\subsection{Thermal Study of the Mixtures}

The results corresponding to the thermal analysis performed on the powdered mixtures by DTA and heating microscopy techniques are reported in Table 2. From DTA curves the glass transition temperature $(\mathrm{Tg})$ is in the range $657-665^{\circ} \mathrm{C}$ and two exothermic peaks, one small at $450-460{ }^{\circ} \mathrm{C}$ (probably due to organic compounds decomposition, derived from the ceramic sludge) and the other indicating a neo formation crystalline phase at $870{ }^{\circ} \mathrm{C}$ are present. Besides, from the heating microscopy measure, it is possible to obtain the characteristic temperatures for the two mixtures (V125 and V75). The results achieved (Table 2) plainly show for both mixtures the reduction of sintering temperature with respect to traditional ceramic materials, encouraging the possibility to employ these mixtures $(<125 \mu \mathrm{m}$ and $<75 \mu \mathrm{m})$ to obtain ceramic supports at lower temperatures with respect to the commercial ones. The positive effect of the granulometry on the densification and softening temperatures is evident, lower values for V75 with respect to V125 were achieved. 
Table 2. Characteristic temperatures determined by DTA and Optical Hot stage microscopy for the two mixtures prepared V125 and V75.

\begin{tabular}{cccccc}
\hline & \multicolumn{2}{c}{ HEATING MICROSCOPY } & \multicolumn{2}{c}{ DTA } \\
\hline \multirow{2}{*}{ MIXES } & $\begin{array}{c}\text { T }\left({ }^{\circ} \mathrm{C}\right) \\
\text { Sintering }\end{array}$ & $\begin{array}{c}\text { T }\left({ }^{\circ} \mathbf{C}\right) \\
\text { Softening }\end{array}$ & $\begin{array}{c}\text { T }\left({ }^{\circ} \mathbf{C}\right) \\
\text { Melting }\end{array}$ & Tg $\left({ }^{\circ} \mathbf{C}\right)$ & $\begin{array}{c}\text { T }\left({ }^{\circ} \mathbf{C}\right) \\
\text { Crystalization }\end{array}$ \\
\hline V125 & 858 & 1090 & 1222 & 665 & 870 \\
V75 & 802 & 876 & 1216 & 657 & 870 \\
\hline
\end{tabular}

In Figure 1 the dilatometric curves of the two mixtures (V125 and V75) are compared. This technique allows to estimate the temperatures corresponding to the beginning of sintering and the maximum sintering rate. No more differences are observed, the curves present a thermal expansion up to $700{ }^{\circ} \mathrm{C}$ and successively the starting of sintering $720{ }^{\circ} \mathrm{C}$ (V75) and $760{ }^{\circ} \mathrm{C}(\mathrm{V} 125)$ with a small shift $\left(40^{\circ} \mathrm{C}\right)$ to lower temperatures for the mixture $<75 \mu \mathrm{m}$; the temperature of maximum sintering rate (identified by the first derivate curve) are 858 and $861{ }^{\circ} \mathrm{C}$, respectively. The data confirm that the particle size distributions chosen are suitable for the sintering process, because smaller particles with a high reactivity fill the holes created by the larger ones and thus the solid volume increases.

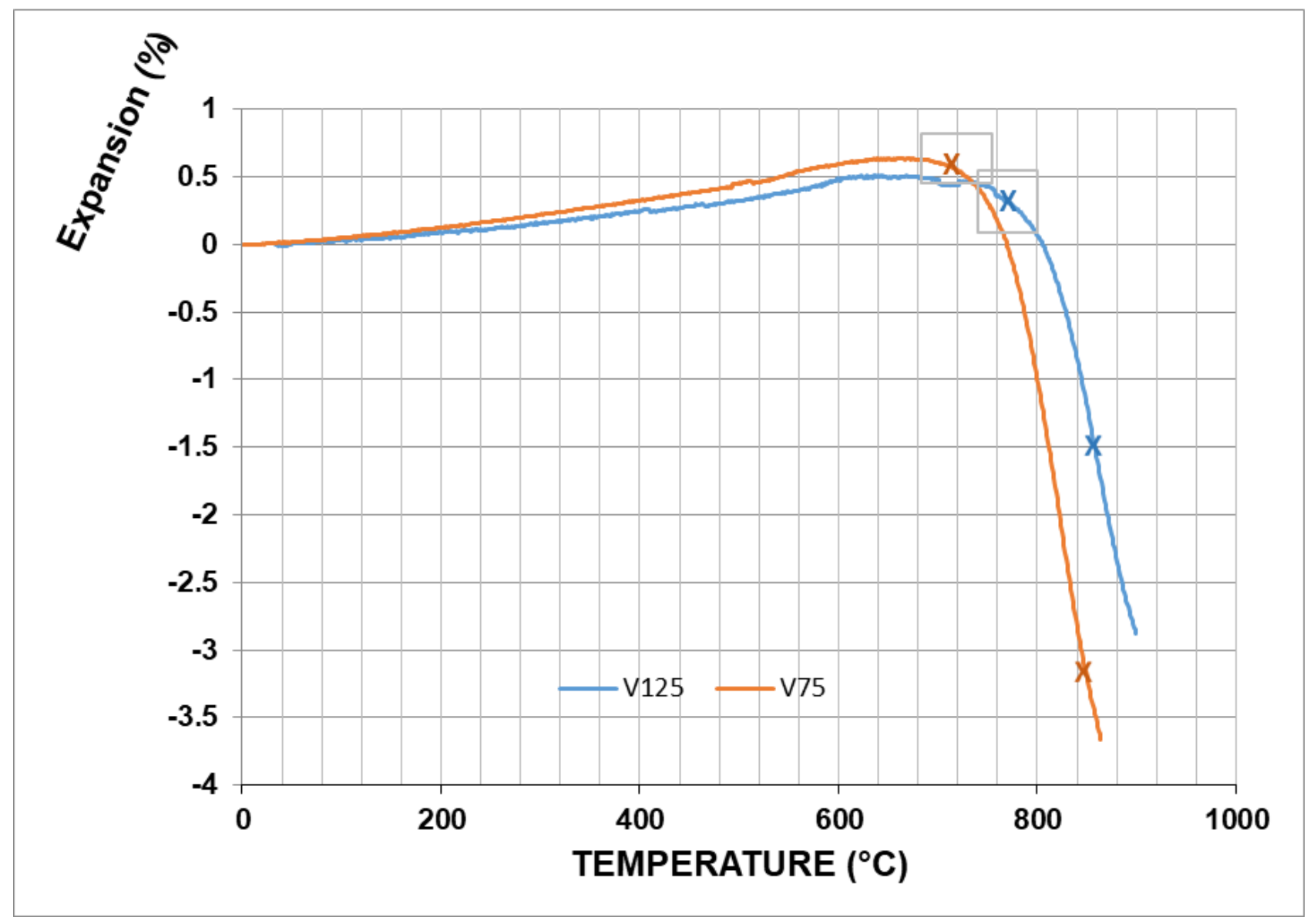

Figure 1. Dilatometric curves for V125 and V75 mixes.

The achieved results show for both mixtures the reduction of sintering temperatures with respect to traditional ceramic tiles. On the basis of the thermal analyses, the pieces were undergone to different heating cycles $\left(800-1000{ }^{\circ} \mathrm{C}\right)$ with a soaking times of 30 and $60 \mathrm{~min}$ for optimizing the densification conditions. 
The sintering degree of the mixtures as a function of thermal treatments was checked by linear shrinkage (L.S\%), water absorption (W.A\%) and apparent density $\left(D_{a p}\right)$.

During firing, chemical, physical, and mineralogical transformations occur in the specimens provoking changes in microstructural and mechanical properties. The most obvious effect is the dimensional change of the samples. Linear shrinkage increases as temperature increases (Figure 2). This trend is positive when it is recognized as an enhancement of densification, this behavior occurs for V75 (Figure 2a) and V125 (Figure 2b) samples treated at $1000{ }^{\circ} \mathrm{C}$ with $60 \mathrm{~min}$ of dwell time. On the basis of these results, it is evident that the particle size distribution contributes to the sintering kinetic. In fact, at the same conditions, sintered samples from the finest powders show higher densification with respect to those with coarse distribution and reach higher values of L.S\%.
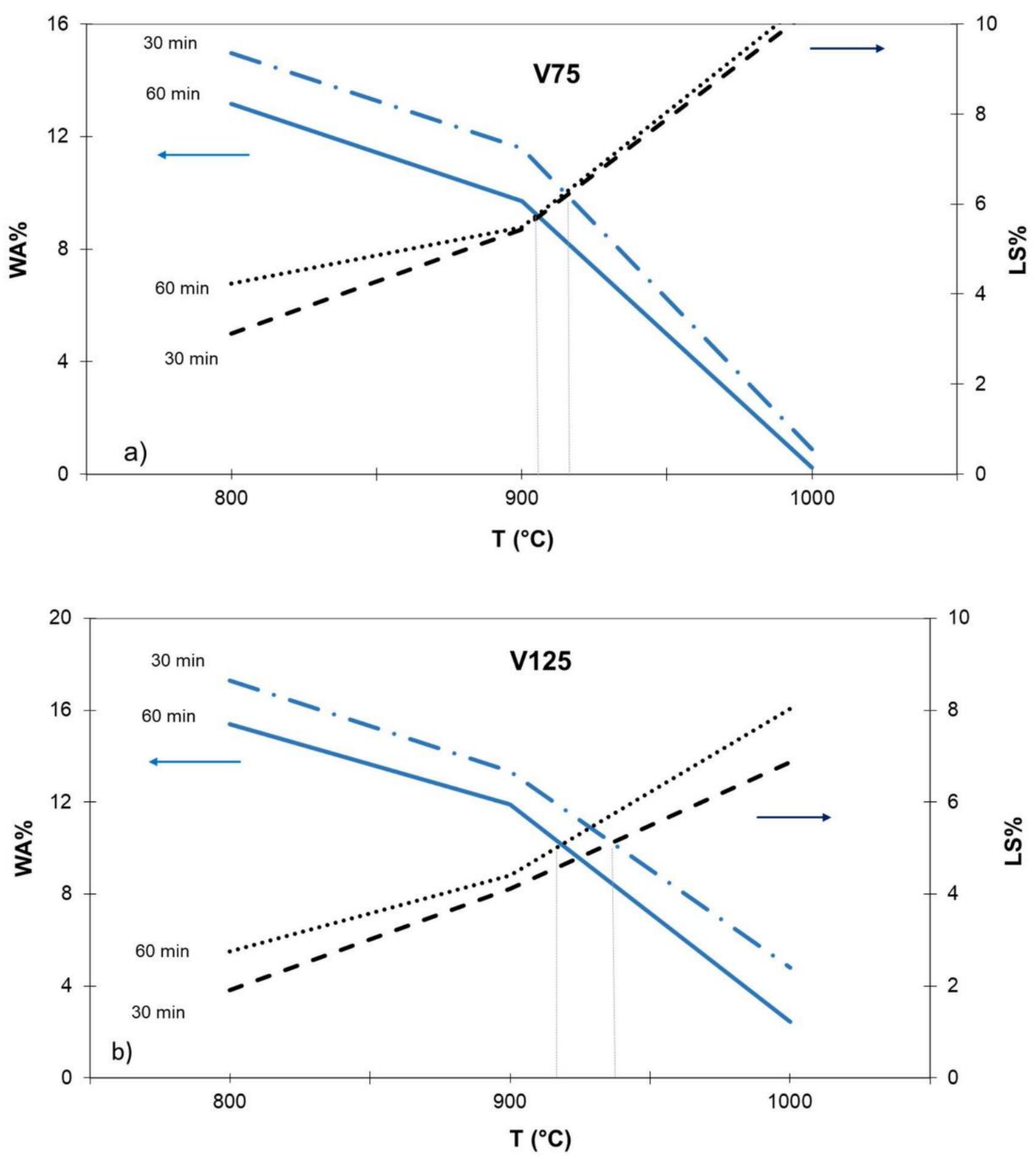

Figure 2. Sintering parameters (LS\% and WA\%) for V75 (a) and V125 (b) mixtures. 
In the same draw WA\% values are plotted as a function of the firing temperatures. The trend decreases when the temperature increases and it is associated with the changes in open or capillary porosity, indicating the progress of sintering process. The density values obtained at $1000{ }^{\circ} \mathrm{C}$ are in line with other study for wollastonbite based glass-ceramics [29].

Confirming the effect of grain size distribution on the densification process in Figure 3 it is possible to observe the density ratio $\left(\mathrm{D}_{\text {absolute }} / \mathrm{D}_{\text {apparent }}\right)$ versus temperature. The monolithic V75 reached a sintering degree of $92 \%$ compared to $83 \%$ of V125 sample at $1000{ }^{\circ} \mathrm{C}$.



Figure 3. $D_{a b s} / D_{a p}$ density ratio vs sintering temperature.

\subsection{Mechanical Properties}

Regarding the elastic properties of materials, Young's modulus (E) is subordinated to the crystalline phases and porosity. As it is known, the elastic properties are affected by the degree of porosity, the presence of pores is considered like a second phase with modulus equal zero, therefore Young's modulus will decrease with an increase of total porosity [34].

In Table 3 it is possible to observe measured E values of V125 and V75 samples at different firing conditions. An increase of $\mathrm{E}$, as a function of the sintering time and temperature was found in agreement with the sintering parameters due to the progressive densification process with formation of crystalline phases. E values around $50 \mathrm{MPa}$ for V125 and higher than $60 \mathrm{MPa}$ for V75 mixture have reached at $1000{ }^{\circ} \mathrm{C}$, in agreement with other studies relative to traditional ceramics [35]. Štubňa et al. (2011) demonstrated the good linearity between Young's modulus and flexural strength (F.S.) for fired ceramics [36]. The following equation permits to calculate F.S. values

$$
\text { F.S. }=1.21 \cdot 10^{-3} \mathrm{E}(\mathrm{MPa}) .
$$

By using this relationship, it is possible to evaluate approximately the flexural strength of fired samples or Young's modulus if one of them is known. Different advantages derive from the use of this method: (i) The elastic modulus does not depend on the sample size; (ii) ultrasonic method used for E determination is a nondestructive method.

As can be observed in Table 3, calculated data for samples V75 and V125 fired at $1000{ }^{\circ} \mathrm{C}$ are higher than the requirement for high sintered commercial floor tiles ( $\geq 35 \mathrm{MPa}$ ) reported in the ISO Rules for Ceramic Tiles [37]. Taking into account the sensitivity of the measurement, the effect of the particle size at $800{ }^{\circ} \mathrm{C}, 30 \mathrm{~min}$ is negligible, the increase of the isotherm time to $60 \mathrm{~min}$ already highlights the difference between the values of $\mathrm{E}$ and F.S. for the two particle size. The mechanical properties increase with temperature reaching 
values similar or better than traditional ceramics at $1000{ }^{\circ} \mathrm{C}$ when a dense polycrystalline material is formed.

Table 3. Apparent and absolute density, elastic, and mechanical properties for the fired samples prepared in laboratory conditions.

\begin{tabular}{|c|c|c|c|c|c|c|c|c|c|c|}
\hline \multirow[t]{2}{*}{$\begin{array}{l}\text { Thermal } \\
\text { Treatment }\end{array}$} & \multicolumn{2}{|c|}{$\begin{array}{l}\text { Apparent Density } \\
\left(\mathrm{kg} / \mathrm{m}^{3}\right)\end{array}$} & \multicolumn{2}{|c|}{$\begin{array}{l}\text { Absolute Density } \\
\left(\mathrm{kg} / \mathrm{m}^{3}\right)\end{array}$} & \multicolumn{2}{|c|}{$\begin{array}{c}\text { Young's Modulus } \\
\text { E (GPa) }\end{array}$} & \multicolumn{2}{|c|}{$\begin{array}{l}\text { Poisson } \\
\text { Ratio }\end{array}$} & \multicolumn{2}{|c|}{ Flexural Strength (MPa) } \\
\hline & V125 & V75 & V125 & V75 & V125 & V75 & V125 & V75 & V125 & V75 \\
\hline $800^{\circ} \mathrm{C}, 30 \mathrm{~min}$ & $1690 \pm 0.007$ & $1720 \pm 0.008$ & n.d & n.d & $12.50 \pm 0.38$ & $13.01 \pm 0.39$ & 0.19 & 0.18 & $15.13 \pm 0.46$ & $15.74 \pm 0.47$ \\
\hline $800^{\circ} \mathrm{C}, 60 \mathrm{~min}$ & $1730 \pm 0.006$ & $1750 \pm 0.007$ & $2562 \pm 0.002$ & $2458 \pm 0.002$ & $14.22 \pm 0.43$ & $19.11 \pm 0.57$ & 0.18 & 0.19 & $17.21 \pm 0.52$ & $23.12 \pm 0.69$ \\
\hline $900^{\circ} \mathrm{C}, 30 \mathrm{~min}$ & $1820 \pm 0.009$ & $1860 \pm 0.006$ & n.d & n.d & $24.19 \pm 0.73$ & $27.13 \pm 0.81$ & 0.20 & 0.20 & $29.27 \pm 0.88$ & $32.83 \pm 1.0$ \\
\hline $900^{\circ} \mathrm{C}, 60 \mathrm{~min}$ & $1840 \pm 0.008$ & $1880 \pm 0.007$ & $2561 \pm 0.003$ & $2461 \pm 0.002$ & $26.88 \pm 0.81$ & $27.95 \pm 0.84$ & 0.20 & 0.21 & $32.55 \pm 1.0$ & $33.82 \pm 1.0$ \\
\hline $1000^{\circ} \mathrm{C}, 30 \mathrm{~min}$ & $2030 \pm 0.007$ & $2260 \pm 0.006$ & n.d & n.d & $38.22 \pm 1.10$ & $50.45 \pm 1.50$ & 0.21 & 0.22 & $46.25 \pm 1.33$ & $61.05 \pm 1.82$ \\
\hline $1000^{\circ} \mathrm{C}, 60 \mathrm{~min}$ & $2130 \pm 0.006$ & $2270 \pm 0.005$ & $2570 \pm 0.003$ & $2472 \pm 0.003$ & $42.13 \pm 1.13$ & $51.05 \pm 1.51$ & 0.21 & 0.23 & $50.98 \pm 1.50$ & $61.77 \pm 1.80$ \\
\hline
\end{tabular}

n.d: not data, did not measured.

The values of Poisson's ratio $(v)$ must fall within the range 0.1 and 0.5 to have positive values of Young's modulus (E), shear modulus (G) and bulk modulus [38]. In our study, the materials obtained have Poisson's ratio values around 0.20 in agreement with most ceramics [39].

\subsection{Mineralogical, MIP, and Microstructural Characterization}

The mineralogical analysis performed on the sintered samples have highlighted that independently by particle size of the mixture (V125, V75), all samples show some crystalline phases: Quartz $\left(\mathrm{SiO}_{2}\right)$ as main crystalline phase (ICDD \#078-2315), albite calcian ordinate $(\mathrm{Na}, \mathrm{Ca})\left(\mathrm{AlSi}_{3} \mathrm{O}_{8}\right)(\mathrm{ICDD} \# 076-0927)$, and wollastonite $\left(\mathrm{CaSiO}_{3}\right)(\mathrm{ICDD} \# 002-$ 0689), as neo-formation phases. Figure 4 reports the evolution of the crystalline phases identified as a function of temperature for V75 mixture. As reported above the two mixes showed similar crystalline phases but the finer mixture (V75) showed higher intensity of the crystalline phases.

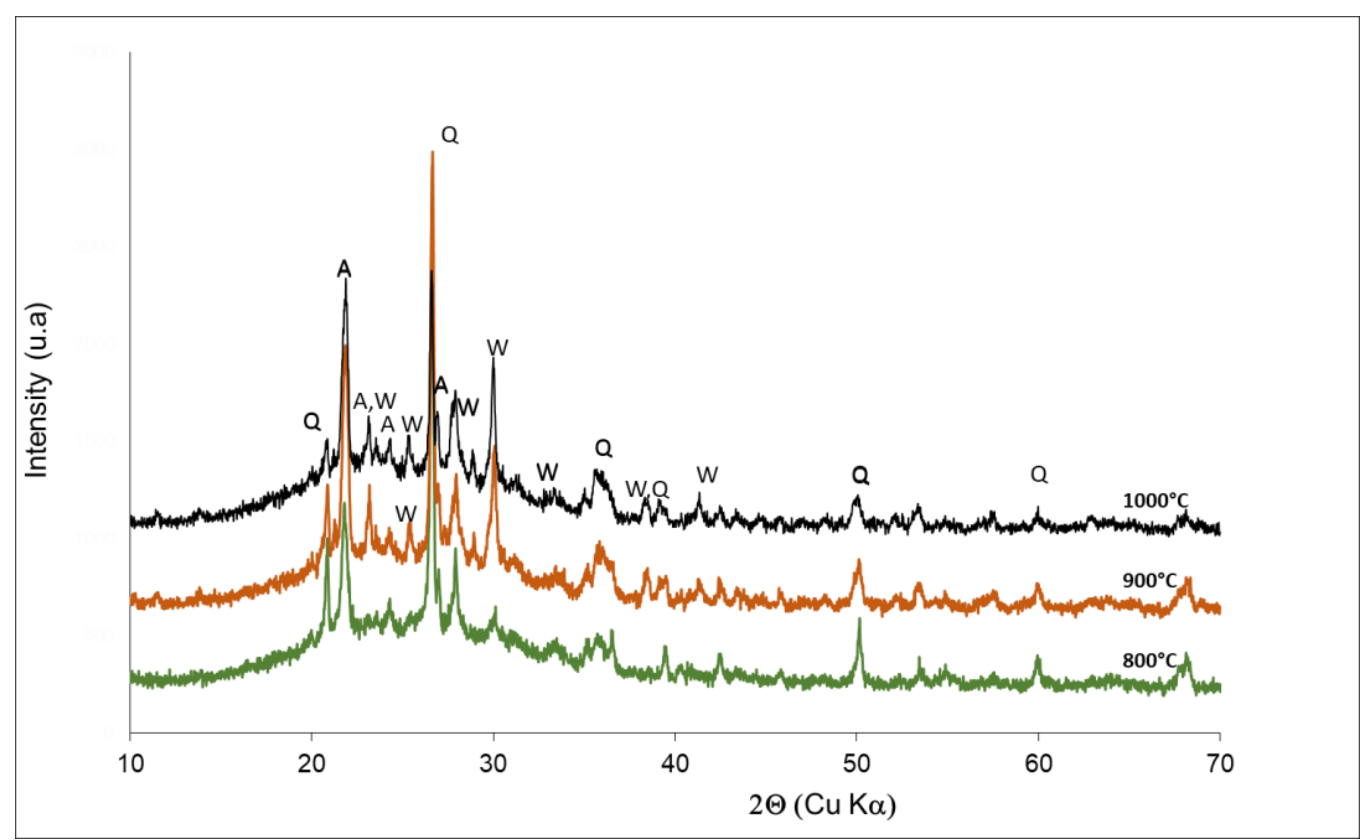

Figure 4. XRD spectrum of the V75 sintered samples at different temperatures (soaking time $60 \mathrm{~min}$ ) showing the development of Q (quartz), W(wollastonite) and A (albite calcian ordinate) crystalline phases. 
Kaolinite $\left(\mathrm{Al}_{2} \mathrm{Si}_{2} \mathrm{O}_{5}(\mathrm{OH})_{4}\right)$, corundum $\left(\mathrm{Al}_{2} \mathrm{O}_{3}\right)$ and calcite $\left(\mathrm{CaCO}_{3}\right)$ phases present in the starting sludge disappeared during thermal treatments. Coarser quartz grains withstand to high temperatures and are present in the sintered product, but it is interesting to note that the increase of temperature provokes a diminution of quartz phase due to the solubility in the glassy phase formed. This statement is demonstrated by the decrease of intensity of the Quartz peak ( $3.34 \AA$ d-spacing): 2884 counts $\left(800{ }^{\circ} \mathrm{C}, 60 \mathrm{~min}\right) ; 2530$ counts (900 $\left.{ }^{\circ} \mathrm{C}, 60 \mathrm{~min}\right) ; 1490$ counts $\left(1000{ }^{\circ} \mathrm{C}, 60 \mathrm{~min}\right)$. The glassy phase is favored by the temperature as evident by the broad band in the range $20-35^{\circ} 2 \Theta$. The newly formed calcium(II) silicates phases probably derived from the solid-state reactions between the calcium oxide (provided by calcite $\left(\mathrm{CaCO}_{3}\right)$ decomposition) with reacting silica $\left(\mathrm{SiO}_{2}\right)$ and corundum $\left(\mathrm{Al}_{2} \mathrm{O}_{3}\right)$ derived from the ceramic sludge. Mullite, the typical crystalline phase of porcelain stoneware tile products it is not present in these sintered materials. The formation of plagioclase phase interferes with the kinetic of mullite formation since the phase formation takes place at minor temperature than that necessary for the mullite one [40]. This is confirmed in studied compositions by DTA data where an exothermic peak is observed around $870{ }^{\circ} \mathrm{C}$.

From the MIP measures, cumulative intrusion curves show the relationship between pore volume and pore diameter in the range of 180 to $0.006 \mu \mathrm{m}$ (Figure 5), these curves permit to observe the effect of the firing temperature on the sintering. Between $800-900{ }^{\circ} \mathrm{C}$ not more differences are found with a trend of porosity decrease ( $28 \%$ to $23 \%)$ by the increase in temperature. The specimens fired at $1000{ }^{\circ} \mathrm{C}$ show a significative decrease of the pore volume indicating a high sintering degree in agreement with the results reported in Figure 3. The pore volume data ranged between $0.1373 \mathrm{~mL} \cdot \mathrm{g}^{-1}\left(800{ }^{\circ} \mathrm{C}\right)$ to $0.043 \mathrm{~mL} \cdot \mathrm{g}^{-1}$ $\left(1000^{\circ} \mathrm{C}\right)$. The decrease in cumulative intrusion is linked to the sintering effect accompanied with densification, which seems to reduce the large pores within the matrix justifying the good values in flexural strength as evidenced in Table 3. The sample fired at $1000{ }^{\circ} \mathrm{C}$, $60 \mathrm{~min}$ showed a porosity of $8 \%$. This trend is in line with the microstructural evolution against with heating temperature from SEM analysis.

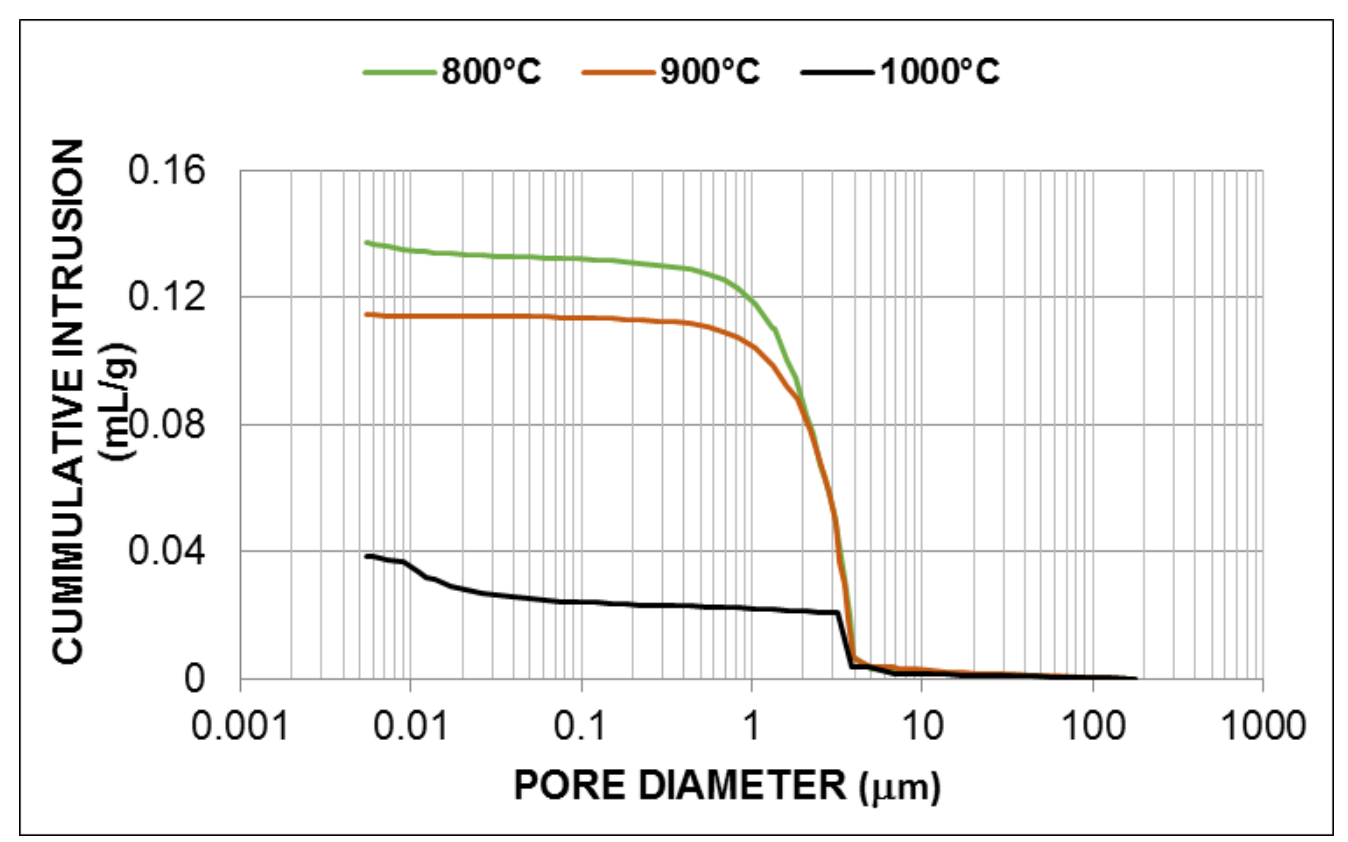

Figure 5. Cumulative intrusion curves of V75 samples fired at different temperatures and $60 \mathrm{~min}$ of dwell time.

The samples at 800 and $900{ }^{\circ} \mathrm{C}$ were characterized by similar cumulative curves with a sigmoid trend that permits to hypothesize the cylindrical shape of the pores [41] (p. 171). 
Regarding the pore size distribution reported in the incremental intrusion curves it is possible to observe that the samples fired at 800 and $900{ }^{\circ} \mathrm{C}$ show similar pore size distributions in the range $0.3-10$ microns with small differences in the height of the main peak $(3.745 \mu \mathrm{m})$ depending on porosity access to mercury. Interesting to note, for the sample fired at $1000{ }^{\circ} \mathrm{C}$, that the size pore shift to diameters lower than 0.1 microns (Figure 6). This trend confirms the modification occurring in ceramic matrix when heated at $1000{ }^{\circ} \mathrm{C}$, $60 \mathrm{~min}$ indicating the absence of open porosity due to the increase of a glassy phase and the presence of residual closed porosity as indicated in the SEM analysis.

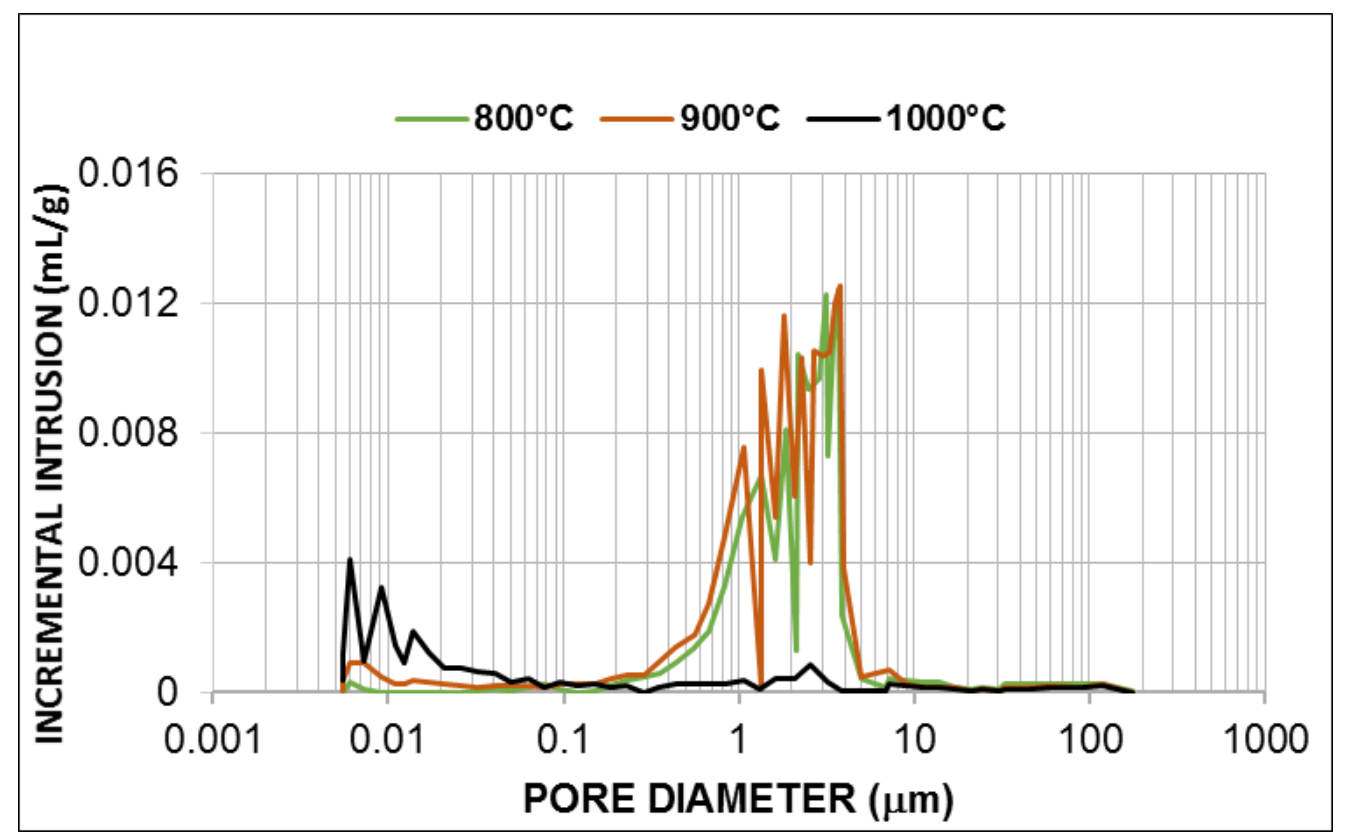

Figure 6. Incremental intrusion curves of V75 samples fired at different temperatures and $60 \mathrm{~min}$ of dwell time.

Microstructural study confirms the XRD analysis, besides evidences the effect of time and temperature on the sintering process and on the corresponding microstructure. Sintered V125 samples showed that thermal treatments up to $900^{\circ} \mathrm{C}$ for $60 \mathrm{~min}$ is not enough to complete the densification. As can be observed in Figure 7a grains of starting materials are already observed corresponding to not completely sintered microstructure. Instead, after treatment at $1000{ }^{\circ} \mathrm{C}$ for $60 \mathrm{~min}$ the microstructure shows a high sintering degree with crystals of neo-formation phases embedded in a glassy phase with residual closed porosity (Figure $7 \mathrm{~b}$ ). Moreover, the investigation of sintered V75 samples at $900{ }^{\circ} \mathrm{C}, 60 \mathrm{~min}$ confirmed the positive effect of grain size on sintering (Figure 7c). The microstructure is similar to that of sample V125 at $1000{ }^{\circ} \mathrm{C}, 60 \mathrm{~min}$. At $1000{ }^{\circ} \mathrm{C}$ the amount of glassy phase is increased closing the large pores and residual closed porosity (Figure $7 \mathrm{~d}$ ). This behavior agrees with the density and shrinkage data from which it is possible to observe an increase of the apparent density due to the viscous densification process (Table 3).

Comparing fired samples at the same temperatures, the time increase highlights an improvement of the sintering process due to the reduction of porosity and both diffusion and growth of crystallites.

In micrograph reported (Figure 8) the main crystalline phases as wollastonite (W) (from EDS analysis $\mathrm{Ca}=34 \%, \mathrm{Si}=24 \%$ and $\mathrm{O}=41 \mathrm{wt} \%$ ), albite (A) (from EDS analysis $\mathrm{Na}=9 \%, \mathrm{Si}=32 \%, \mathrm{Al}=10 \%$ and $\mathrm{O}=49 \mathrm{wt} \%$ ) and quartz (Q) (from EDS analysis $\mathrm{Si}=45 \%, \mathrm{O}=55 \mathrm{wt} \%$ ) and white grains of $\mathrm{Zr}$ silicate (derived from decoration components presents in the ceramic sludge) were identified. It is possible to observe the characteristic morphology (acicular and dendritic crystals, plates, and granules) of the different phases identified. Besides, the EDS analysis confirmed the composition of glassy phase (sodium- 
calcium silicate glass) and the presence of white agglomerates corresponding to unfused oxides of $\mathrm{Cr}$ and $\mathrm{Fe}$ (present in the ceramic sludge). These spectra are reported in the supplementary data.

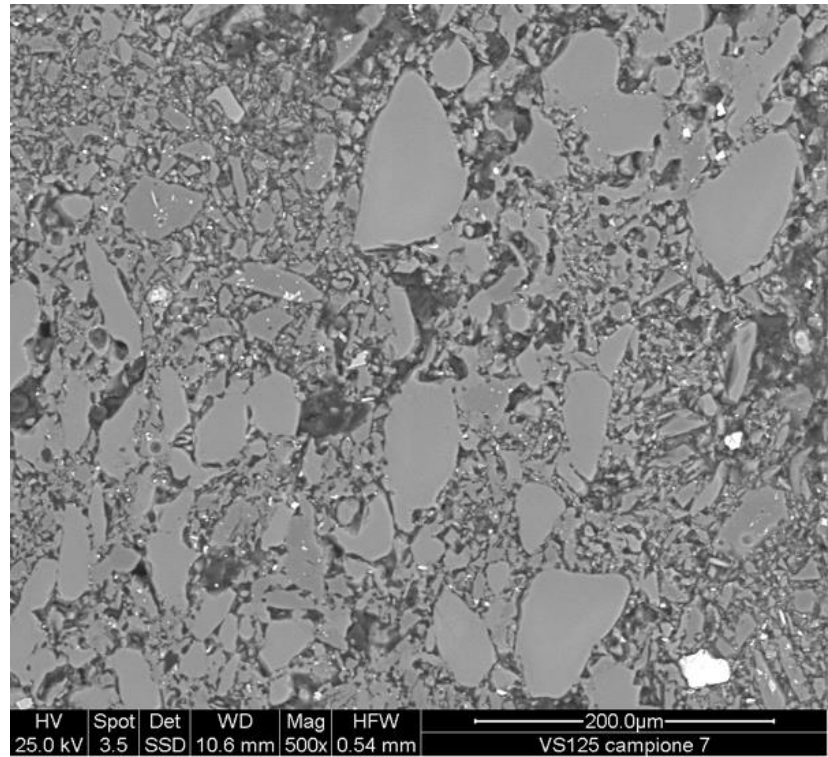

(a)

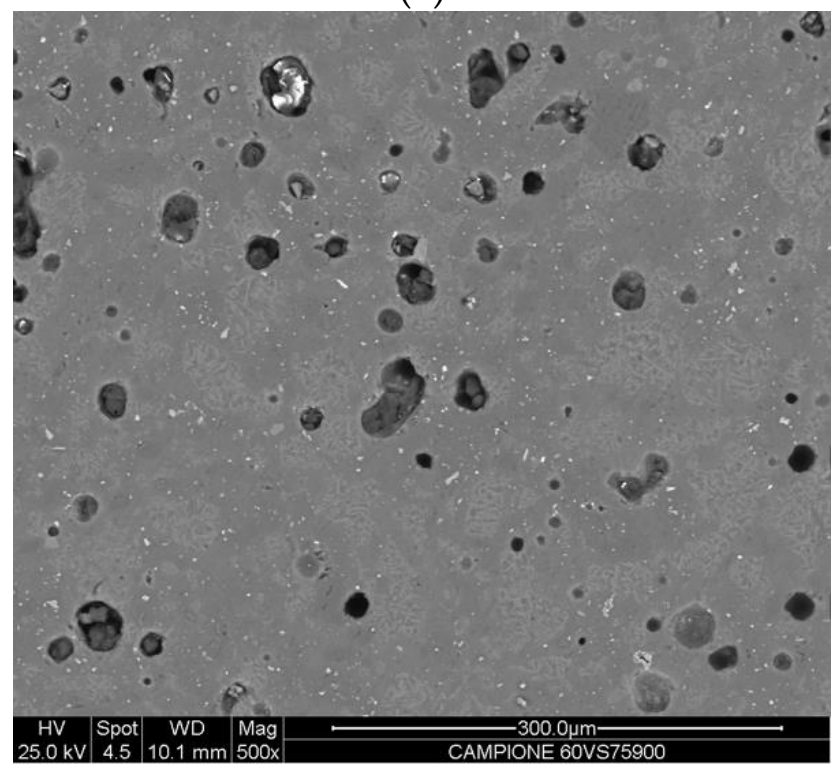

(c)



(b)



(d)

Figure 7. SEM cross micrographs: (a) V125 $900{ }^{\circ} \mathrm{C}, 60 \mathrm{~min}$; (b) V125 $1000{ }^{\circ} \mathrm{C}, 60 \mathrm{~min}$; (c) V75 $900{ }^{\circ} \mathrm{C}, 60 \mathrm{~min}$ and (d) V75 $1000{ }^{\circ} \mathrm{C}, 60 \mathrm{~min}$.

\subsection{Chemical and Stain Resistance}

The acid resistance test related to unglazed tiles was chosen for the characterization of these materials. The specimens were submerged in acid solution ( $\mathrm{HCl} 3 \%$ vol.) for 12 days, after this time they were immersed in water for 5 days, then dried and the surface and edges by a visual check were evaluated. The samples can be classified into three classes: Class ULA (not visible effect); ULB (visible effect on the edges); ULC (visible effect on the surface and edges). 


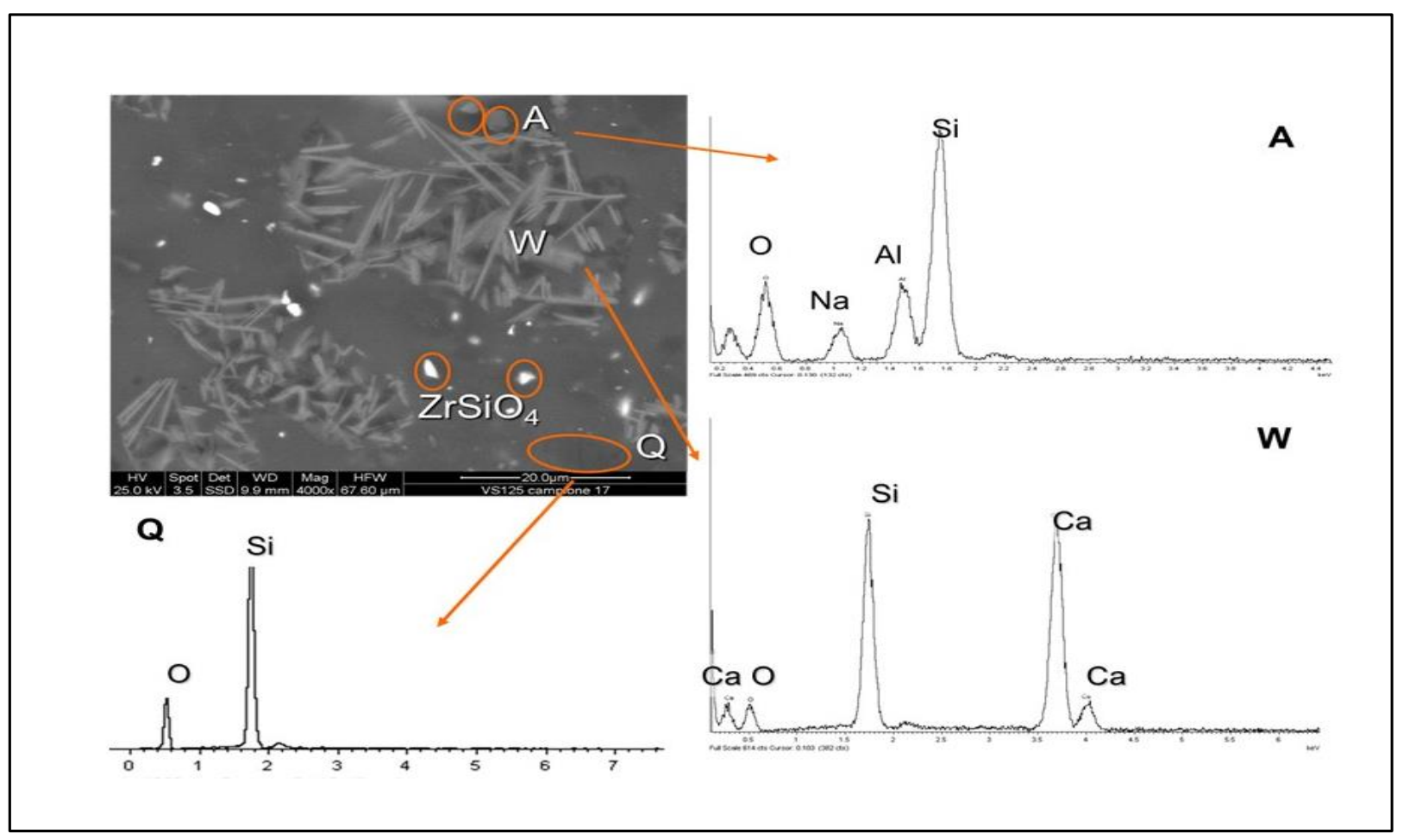

Figure 8. Micrograph and EDS spectra relative to V125 at $1000^{\circ} \mathrm{C}, 60 \mathrm{~min}$. $\mathrm{W}=$ wollastonite, $\mathrm{A}=$ albite, $\mathrm{Q}=\mathrm{quartz}$.

The acid resistance test pointed out good results (ULA) only for samples V125 and V75 fired at $1000{ }^{\circ} \mathrm{C}$ in agreement with low water absorption values obtained. From the above results, it is deduced high durability to the acid attack of the formed glassy phase which covers the open pores of the materials obtained.

Further, the staining test is a typical example of an indirect verification of the capillary porosity. For carrying out the test, a paste prepared with green pigment in olive oil (as a colorant) was used.

3-4 drops were poured over the surface of the samples and kept covered for $24 \mathrm{~h}$ to check the degree of absorption. Then, the surface have been cleansed with different cleaning agents. The samples can be classified in five classes: Class 5 (spot removed by warm water $\left(55^{\circ} \mathrm{C}\right)$ ); Class 4 (spot removed by neutral detersive agent); Class 3 (spot removed by strong detersive agent); Class 2 (spot removed after immersion $24 \mathrm{~h}$ by a solvent); Class 1 (spot not removed).

The performed test pointed out a decrease in the stain color intensity proportional to the sintering degree: Class 5 for the samples fired at $1000{ }^{\circ} \mathrm{C}$, Class 4 for samples fired at $900{ }^{\circ} \mathrm{C}$ and Class 1 for the samples fired at $800{ }^{\circ} \mathrm{C}$.

\subsection{Leaching Test}

Several studies on heavy metals immobilization suggested thermal treatments based on sintering or vitrification as the best way to obtain an environmentally stable waste [42,43]. Glass-ceramics, being fine-grained polycrystalline material with a glassy phase, in the recent years, are referred to a metal immobilizer with the advantage of add-value marketable products $[28,44]$.

Nowadays, In Italy, there is not a suitable test to verify the leaching onto "ceramic tiles" made using alternative raw materials (in this case waste). For this reason, choosing the most unfavorable case, it was selected the methodology following UNI 10802(EN12457, 2002) specific for residues. The results of this test permits to classify the waste as inert, not hazardous, or hazardous following the Italian Normative [45]. Despite this, the test is indicative to understand the danger in using waste in a new process or in a new product. The ceramic sludge (used as secondary raw material) contains small amounts of heavy 
metals such as $\mathrm{Pb}, \mathrm{Cu}, \mathrm{Cr}$, and $\mathrm{Ba}$ (derived from frits and pigments). To evaluate if, after thermal treatment, the materials obtained are inert and suitable for use, an investigation of hazardous substance mobility was performed on the fired samples. Metals leachability has been evaluated in both the eluates coming from received sludge and fired materials containing the sludge. The metals content detected in the eluates was compared. For this analysis V125 and V75 samples after firing at $1000{ }^{\circ} \mathrm{C}, 60 \mathrm{~min}$ were considered. The results were compared to the eluates concentration limits for acceptability in landfills for inert waste. The data obtained is reported in Table 4 .

Table 4. Leaching test for glazing sludge and the V125 and V75 sintered samples compared to the Italian regulation limits.

\begin{tabular}{|c|c|c|c|c|}
\hline $\begin{array}{l}\text { Parameters/Anions/ } \\
\text { Elements }\end{array}$ & Glazing Sludge & Vs125 & V75 & $\begin{array}{c}\text { Italian Regulation Limit for Inert } \\
\text { Landfill Disposal } \\
\text { D.m.27/9/2010 }\end{array}$ \\
\hline $\mathrm{pH}$ a $20^{\circ} \mathrm{C}$ & 8.63 & 9.82 & 9.91 & $5.5-12.0$ \\
\hline Specific conductivity ( $\mu \mathrm{S} / \mathrm{cm})$ & 145 & 62.0 & 65.4 & - \\
\hline Nitrate $(\mathrm{mg} / \mathrm{L})$ & $<0.02$ & $<0.02$ & $<0.02$ & 50 \\
\hline Sulphate $(\mathrm{mg} / \mathrm{L})$ & 15.8 & 2.0 & 2.7 & 100 \\
\hline Chloride (mg/L) & 8.45 & 0.27 & 0.43 & 80 \\
\hline Fluorine (mg/L) & 1.17 & 0.035 & 0.012 & 1 \\
\hline Cr total $(\mu \mathrm{g} / \mathrm{L})$ & 18.5 & 11.4 & 6.30 & 50 \\
\hline $\mathrm{Cd}(\mu \mathrm{g} / \mathrm{L})$ & $<1$ & $<1$ & $<1$ & 4 \\
\hline $\mathrm{Cu}(\mu \mathrm{g} / \mathrm{L})$ & 37.9 & 2.10 & 3.33 & 20 \\
\hline $\mathrm{Pb}(\mu \mathrm{g} / \mathrm{L})$ & 184.8 & 3.80 & 1.20 & 50 \\
\hline $\mathrm{Al}(\mathrm{mg} / \mathrm{L})$ & 0.50 & 0.50 & 0.60 & - \\
\hline As (mg/L) & $<0.05$ & $<0.05$ & $<0.05$ & 0.05 \\
\hline $\mathrm{Ba}(\mathrm{mg} / \mathrm{L})$ & $<1$ & $<1$ & $<1$ & 2 \\
\hline Co $(\mathrm{mg} / \mathrm{L})$ & $<0.02$ & $<0.02$ & $<0.02$ & 0.25 \\
\hline $\mathrm{Fe}(\mathrm{mg} / \mathrm{L})$ & $<0.02$ & $<0.02$ & $<0.02$ & - \\
\hline $\mathrm{Mn}(\mathrm{mg} / \mathrm{L})$ & $<0.02$ & $<0.02$ & $<0.02$ & - \\
\hline $\mathrm{Zn}(\mathrm{mg} / \mathrm{L})$ & 0.50 & $<0.50$ & $<0.50$ & 0.40 \\
\hline
\end{tabular}

Good results were obtained from both $\mathrm{pH}$ and specific conductivity measures; $\mathrm{pH}$ values for the "end products" are within the rule range (5.5-12.0). The increase with respect to the sludge probably is due to the presence of alkaline and alkaline-earth ions release from the glass cullet present in the mixture. On the contrary the conductivity values are lower than the as-received sludge. These data confirmed that the residual glassy phase present into the sintered materials acts immobilizing the ions embedded in the matrix showing a lower release with respect to the sludge's sample.

Regarding metals eluate, the ceramic sludge shows a high release of some heavy metals, in particular, lead $(\mathrm{Pb})$ value surpasses the regulation limit. The explanation lies in the fact that sludge is a mixture of materials with very different chemical nature as frits, ceramics and other components (pigments, oxides) that are not capable of binding heavy metals that can be released.

Instead, it is possible to observe that V125 and V75 densified samples show significantly reduced values compared to the as received sludge, indeed, the mobility of metals like $\mathrm{Pb}, \mathrm{Cu}, \mathrm{Cr}$ and anions as chlorine, fluorine and sulphates are strongly reduced ( $\mathrm{Pb}$ 50-150 times; Cr 20 times, ... ) and shows values below Italian regulation limits demonstrating that the obtained materials are inert without provoking further environmental impact.

\subsection{Semi-Industrial Experimentation}

Satisfactory laboratory scale and leaching tests permitted to hypothesize the obtainment of ceramic materials suitable as floor or wall tiles. These products reached good features at temperatures $\left(900-1000{ }^{\circ} \mathrm{C}\right)$ with $60 \mathrm{~min}$ of isotherm time, surely energy-saving 
conditions with respect to commercial products $\left(1100-1250{ }^{\circ} \mathrm{C}\right)$ and furthermore, using alternative raw materials saving the natural resources.

Samples of V75 composition were undergone by three traditional industrial cycles (described above). The sintering degree on the fired pieces was checked by the determination of W.A.\%, L.S\%, Apparent Density and Young's modulus (E). Flexural Strength calculated by Equation (4) completes the characterization. The experimental data reported in Table 5 were left as an interval between the lowest and the highest value obtained in order to compare them with the typical data of commercial products.

Table 5. Sintering parameters, elastic and mechanical properties for samples fired by industrial cycles.

\begin{tabular}{|c|c|c|c|c|c|}
\hline $\begin{array}{l}\text { Industrial } \\
\text { Thermal } \\
\text { Treatment }\end{array}$ & $\begin{array}{c}\text { Water Absorption } \\
\text { W.A.\% }\end{array}$ & $\begin{array}{c}\text { Linear Srinkage } \\
\text { L.S. } \%\end{array}$ & $\begin{array}{l}\text { Apparent Density } \\
\text { A.D. }\left(\mathrm{kg} / \mathrm{m}^{3}\right)\end{array}$ & $\begin{array}{c}\text { Young's Modulus } \\
\text { E(GPa) }\end{array}$ & $\begin{array}{c}\text { Flexural Strength } \\
(\mathrm{MPa})\end{array}$ \\
\hline$\left(960^{\circ} \mathrm{C}, 50 \mathrm{~min}.\right)$ & $8.2 \div 11.0$ & $5.55 \div 6.25$ & $1908 \pm 0.006$ & $21.68 \div 31.14$ & $26.23 \div 37.67$ \\
\hline (1020 $\left.{ }^{\circ} \mathrm{C}, 54 \mathrm{~min}.\right)$ & $6.6 \div 8.6$ & $6.72 \div 7.42$ & $2025 \pm 0.005$ & $34.51 \div 37.54$ & $41.76 \div 45.42$ \\
\hline (1087 $\left.{ }^{\circ} \mathrm{C}, 41 \mathrm{~min}.\right)$ & $0.04 \div 0.09$ & $11.34 \div 11.72$ & $2281 \pm 0.007$ & $57.03 \div 57.63$ & $69.00 \div 69.80$ \\
\hline Commercial & $\mathrm{BIa} \leq 0.5$ & & & & $\geq 35$ \\
\hline products & $\mathrm{BIb}>0.5 \div 3$ & $7.0 \div 8.0$ & $2000 \div 2400$ & $20 \div 60$ & $\geq 30$ \\
\hline$\left(1100-1250^{\circ} \mathrm{C}\right)$ & BIIa $>3 \div 6$ & & & & $\geq 22$ \\
\hline
\end{tabular}

From Table 5 it is possible to note that the optimum temperature range is around $1020-1090^{\circ} \mathrm{C}$. In particular, regarding water absorption at $1087^{\circ} \mathrm{C}$, the low values permit to classify these materials into BIa Group according to ISO 13006 rule (BIa W.A $\% \leq 0.5 \%$ ). The properties achieved by these samples are compared to those corresponding to commercial porcelain stoneware products (firing at $\left.1200-1250{ }^{\circ} \mathrm{C}\right)$. The cycle $\left(1020^{\circ} \mathrm{C}, 54 \mathrm{~min}\right.$.) could be the most appropriate with a LS\% value similar to the commercial products. Regarding water absorption the data are high respect to commercial tiles but it is important to note that all the determinations were conducted on the unglazed materials (support) as a monolithic similar to technical porcelain stoneware or clinker. Surely, glazed products obtained by the cycle at $1020^{\circ} \mathrm{C}$ could reach good values of water absorption, too. Mechanical properties obtained are higher than those relative to commercial tiles used as covering for floors and walls (see Table 5).

In the case to use the products without glazing, the cycle at $1087^{\circ} \mathrm{C}$ produced specimens with lowest W.A\% but higher L.S.\% values, this fact can cause calibration problems after firing. In order to optimize the linear shrinkage, future developments of the research have scheduled the reformulation of the mixture introducing a reducing plasticity material (for example rice husk ash).

\section{Conclusions}

This study suggests the feasibility to obtain eco-compatible building materials for covering floor or wall using a mixture of ceramic sludge and packaging glass cullet.

As known a huge amount of natural raw materials (90 Gigatonnes/y) is used to produce construction materials worldwide. Considering the high production of ceramic materials and the demonstrated capacity of the ceramic matrix to fix metals, this way permits to use silicate wastes by transformation into useful ceramic tiles products.

In fact, the leaching tests demonstrated that the sintering process at temperatures around $1000{ }^{\circ} \mathrm{C}$ permits the formation of a glass-ceramic matrix that acts to immobilize the metals ions. All the measured parameters are lower that the Italian regulation limits confirming the obtainment of inert materials.

The proposed process using sludge that acts as fluxing materials permits to fire at lower temperatures $\left(<200^{\circ} \mathrm{C}\right)$ than traditional cycles used for commercial ceramic tiles products. Concerning the sintering properties, the end products fired at temperatures around $1000{ }^{\circ} \mathrm{C}$, comparable WA $\%$ and $\mathrm{LS} \%$ values with respect to traditional wall ceramic 
tiles. Besides, they showed flexural strength values higher than the minimum required by European Standard norm (ISO 13006) for commercial tiles already on the market.

Several advantages give to this research an important environmental footprint in the sustainability field: (a) Avoiding the landfilling of ceramic sludge; (b) avoiding the depletion of natural raw materials; (c) saving energy and greenhouse gas emission by reduction of firing temperature; (d) leaching results show that the design of materials from waste that does not cause further pollution.

Considering that these products contain large amounts of sludge residue and postconsumer glass material, they can be positively accepted by the market, taking into account the certifications as LEED (Leadership in Energy and Environmental Design) and ECOLABEL.

Supplementary Materials: The following are available online at https: / www.mdpi.com/article/ 10.3390/app11083545/s1, Figure S1: EDS Spectrum of V125 fired $1000{ }^{\circ} \mathrm{C}, 60 \mathrm{~min}$.

Author Contributions: Conceptualization F.A., L.B., and I.L.; methodology, F.A., L.B., I.L., and P.P.; validation, F.A., L.B., I.L., and P.P.; formal analysis, F.A.; investigation, F.A., L.B., I.L., and P.P.; data curation, F.A.; writing - original draft preparation, F.A.; writing - review and editing, F.A., L.B., and I.L.; visualization, F.A., L.B., I.L., and P.P.; supervision, L.B. project administration, L.B. All authors have read and agreed to the published version of the manuscript.

Funding: The authors declare that this research received no external funding.

Institutional Review Board Statement: Not applicable.

Informed Consent Statement: Not applicable.

Data Availability Statement: Not applicable.

Conflicts of Interest: The authors declare no conflict of interest.

\section{References}

1. ZerowasteEurope. 2015. Available online: https://zerowasteeurope.eu/2015/05/walking-the-circle/ (accessed on 11 May 2020).

2. Lieder, M.; Rashid, A. Towards circular economy implementation: A comprehensive review in context of manufacturing industry. J. Clean. Prod. 2016, 115, 36-51. [CrossRef]

3. EU.COM 0614. Action Plan. Closing the Loop-an EU Action Plan for the Circular Economy. 2015. Available online: https: //www.eea.europa.eu/policy-documents/com-2015-0614-final (accessed on 17 September 2020).

4. Boons, F.; Montalvo, C.; Quist, J.; Wagner, M. Sustainable innovation, business models and economic performance: An overview. J. Clean. Prod. 2013, 45, 9-19. [CrossRef]

5. $39^{\circ}$ National Statistical Report; Ceramic Tiles Italian Business Association (CTIBA): Sassuolo, Italy, 2018.

6. Le Piastrelle Statistiche e Produttori. Available online: https://www.fratellipellizzari.it/blog/piastrelle-produttori (accessed on 22 January 2021).

7. Andreola, F.; Manfredini, T.; Pellacani, G.C.; Pozzi, P. Recycling of ceramic wastes in tile bodies to reduce pollution. Bull. Amer. Ceram. Soc. 1993, 72, 65-70.

8. Andreola, F.; Barbieri, L.; Lancelloti, I.; Manfredini, T. Recycling on the Italian Ceramic Tile Factories in Enviromental Issues and Waste Management Technologies VI. Cer. Trasc. 2001, 119, 85-91.

9. Boschi, G.; Masi, G.; Bonvicini, G.; Bignozzi, M.C. Sustainability in Italian Ceramic Tile Production: Evaluation of the Environmental Impact. Appl. Sci. 2020, 10, 9063. [CrossRef]

10. Report 2010-2015. In Industries Producing Ceramic Tiles-Impact Factors and Environmental Performance; Ceramic Tiles Italian Business Association (CTIBA): Sassuolo, Italy, 2017.

11. Decision 2009/607 CE-"Ecological Criteria for the Assignment of the Community Eco-Label for Hard Coverings" (Ecolabel); Official Journal of the European Union: Luxembourg, 2009.

12. Enrique, J.E.; Monfort, E.; Ferrando, F.; Negre, F. Elimination of boron from waster produced in the ceramic industry. In Proceedings of the 7th Mediterranean Congress of Chemical Engineering, Barcelona, Spain, 22-24 October 1996; Sociedad Espanñola de Quimica, Industrial e Ingenieria Quimica: Barcelona, Spain.

13. Blasco, A.; Escardino, A.; Busani, G.; Monfort, E.; Amoros, J.L.; Enrique, J.E.; Beltran, V.; Negre, F. Tratamiento de Emisiones Gaseosas. Efluentes Liquidos y Residuos Solidos de la Industria Ceramica; AICE-ITC: Castellòn, Spain, 1992.

14. Andreola, F.; Barbieri, L.; Lancelloti, I.; Bignozzi Ma, C.; Sandrolini, F. New blended cement from polishing and glazing ceramic sludges. Int. J. Appl. Ceram. Technol. 2010, 7, 546-555. [CrossRef]

15. Integrated Report for Ceramic Tiles Sector. In Safety, Environment, Energy, Health, Quality; Ceramic Tiles Business Association (CTIBA): Sassuolo, Italy, 2018. 
16. Andreola, F.; Barbieri, L.; Lancelloti, I.; Manfredini, T. Recycling of the waste waters on the porcelainized stoneware ceramic tiles: Effect on the rheological, thermal and aesthetical properties in Enviromental Issues and Waste Management Technologies in the Ceramic and Nuclear Industries VII. Cer. Trasc. 2002, 132, 21-29.

17. Nandia, V.S.; Raupp-Pereira, F.; Montedo, O.R.K.; Oliveira, A.P.N. The use of ceramic sludge and recycled glass to obtain engobes for manufacturing ceramic tiles. J. Clean. Prod. 2015, 86, 461-470. [CrossRef]

18. European Waste Cataloghe (EWC) in European Commission Decision 2000/532/EC, Annex III to Directive 2008/98/EC; Official Journal of the European Union: Luxembourg, 2000.

19. Guidance on Using the European Waste Catalogue (EWC); Scottish Environment Protection Agency (SEPA): Stirling, Scotland, November 2015. Available online: https://www.sepa.org.uk/media/163421/ewc_guidance.pdf (accessed on 17 September 2020).

20. Pereira, F.R.; Nunes, A.P.; Segadaes, A.M.; Labrincha, J.A. Refractory mortars made of different wastes and natural sub-products. Key Eng. Mater. 2004, 264-268, 1743-1747. [CrossRef]

21. Albuquerque, M.; Flores, J.M.; Labrincha, J.A. Reuse of sludge generated in wastewater plant of glaze applying processes by direct incorporation in engobe formulations. Ind. Ceram. 2002, 22, 87-92.

22. Monfort, E.; Bou, E.; Celades, I.; Moreno, G.S.; Castellón's, J.I.; Cruz, R.; Martí's, V.; Portolés's, J.; Castellón's, S.A. Valorization of Sludge for Glaze Production. Ind. Ceram. Verre 2003, 991, 44-48.

23. De Silva Subashi, G.H.M.J.; Hansamali, E. Eco-friendly fired clay bricks incorporated with porcelain ceramic sludge. Constr. Build. Mat. 2019, 228, 116754. [CrossRef]

24. Garcia, C.M.; Iglesias, F.A.I.; Pérez-Villarejo, L.; Iglesias-Godino, F.J.; Corpas-Iglesias, F.A. Sludge valorization from wastewater treatment plant to its application on the ceramic industry. J. Environ. Manag. 2012, 95, S343-S348. [CrossRef] [PubMed]

25. García-Ten, F.J.; Quereda Vázquez, M.F.; Gil Albalat, C.; Chumillas Villalba, D.; Zaera, V.; Segura Mestre, M.C. Life Ceram-Zero Waste in Ceramic Tile Manufacture. Key Eng. Mat. 2015, 663, 23-33. [CrossRef]

26. Coletti, C.; Maritan, L.; Cultrone, G.; Mazzoli, C. Use of industrial ceramic sludge in brick production: Effect on aesthetic quality and physical properties. Constr. Build. Mater. 2016, 124, 219-227. [CrossRef]

27. de Rojas Ma Sanchez, I.; Frıas, M.; Sabador, E.; Asensio, E.; Rivera, J.; Medina, C. Use of ceramic industry milling and glazing waste as an active addition in cement. J. Am Ceram Soc. 2018, 101, 2028-2037. [CrossRef]

28. Rawlings, D.; Wu, J.P.; Boccaccini, A.R. Glass ceramics: Their production from wastes. A review. J. Mat. Sc. 2006, 41, 733-761. [CrossRef]

29. Almasri, K.A.; Aziz Sidek, H.A.; Matori, K.A.; Zaid, M.H.M. Effect of sintering temperature on physical, structural and optical properties of wollastonite based glass-ceramic derived from waste soda lime silica glasses. Results Phys. 2017, 7, $2242-2247$. [CrossRef]

30. Yoon, S.D.; Lee, J.-U.; Lee, J.-H.; Yun, Y.H.; Yoon, W.J. Characterization of Wollastonite Glass-ceramics Made from Waste Glass and Coal Fly Ash. J. Mater. Sci. Technol. 2013, 29, 149-153. [CrossRef]

31. Oficial Web Site Micromeritics. Available online: www.micromeritics.com (accessed on 14 January 2021).

32. Degen, T.; Sadki, M.; Bron, E.; König, U.; Nénert, G. The High Score Suite in Powder Diffraction; Cambridge University Press: Cambridge, UK, December 2014; Volume 29, (Suppl. S2), pp. S13-S18. [CrossRef]

33. Heritage, K.; Frisby, C.; Wolfender, M. Impulse excitation technique for dynamic flexural measurements at moderate temperature. Rev. Sci. Instrum. 1988, 59, 973-974. [CrossRef]

34. Pickup, R. Effect of porosity on the Young modulus of porcelain. Br. Cer. Trasc. 1997, 96, 96-98.

35. Eren, E.; Kurama, S. Characterization of Mechanical Properties of Porcelain Tile Using Ultrasonics. GU J. Sci. 2012, 25, 761-768.

36. Štubňa, I.; Trník, A.; Šín, P.; Sokolár, R.; Medved, I. Relationship between mechanical strength and Young's modulus in traditional ceramics. Mater. Technol. 2011, 45, 375-378.

37. ISO 13006 Ceramic Tiles Rule International Standards-Ceramic Tiles: Definitions, Classification, Characteristics and Marking; ISO, Geneva, Switzerland. 2006. Available online: https://www.iso.org/standard/63406.html (accessed on 14 April 2021).

38. Boccaccini, D.N.; Boccaccini, A.R. Dependence of ultrasonic velocity on porosity and pore shape in sintered materials. J. Nondestruct Eval. 1997, 16, 187-192. [CrossRef]

39. Gercek, H. Poisson's ratio values for rocks. Int. J. Rock Mech. Min. Sci. 2007, 44, 1-13. [CrossRef]

40. Andreola, F.; Bonfatti, L.; Manfredini, T.; Pellacani, G.C.; Pozzi, P. Addition of exhausted lime in ceramic bodies: Possibilities for an environmentally compatible tile production. Part II: Thermal behaviour of bodies. Tile Brick Int. 1992, 8, 341-346.

41. Webb, P.A.; Orr, C. Charper 4, Pore Structure in MIP in Analytical Methods in Fine Particle Technology, 1st ed.; Micromeritics Corporation: Norcross, GA, USA, 1997; pp. 155-191.

42. Guo, B.; Liu, B.; Yang, J.; Zhang, S. The mechanisms of heavy metal immobilization by cementitious material treatments and thermal treatments: A review. J. Environ. Manag. 2017, 193, 410-422. [CrossRef] [PubMed]

43. Quina, M.J.; Bordado, J.C.; Quinta-Ferreira, R.M. Treatment and use of air pollution control residues from MSW incineration: An overview. Waste Manag. 2008, 28, 2097-2121. [CrossRef]

44. Colombo, P.; Brusatin, G.; Bernardo, E.; Scarinci, G. Inertization and reuse of waste materials by vitrification and fabrication of glass-based products. Curr. Opin. Solid State Mat. Sci. 2003, 7, 225-239. [CrossRef]

45. Italian Regulation. D.M. 27 /09/2010. In Definition of the Criteria for Admittance of Waste in Landfills, Replacing Those Contained in the D.M 3/08/2005; Italian Official Gazette: Rome, Italy, 2010. 